\title{
PENERAPAN KUMULASI SANKSI EKSTERNAL DALAM PENEGAKAN HUKUM PIDANA KORUPSI OLEH PEJABAT PEMERINTAHAN DI KABUPATEN SLEMAN
}

\author{
G.Aryadi dan Y.Sri Pudyatmoko \\ Fakultas Hukum Universitas Atmajaya Yogyakarta \\ Korespodensi:pudy07@gmail.com
}

Naskah dikirim: 23 November 2019; |Direvisi: 2 Januari 2020 |Disetujui: 30 Maret 2020

\begin{abstract}
Abstrak
Permasalahan yang diangkat dalam penelitian ini adalah mengenai bagaimana pertimbangan hukum dari hakim dan pejabat pemerintahan yang berwenang melakukan penegakan hukum administrasi dalam menyelesaikan kasus korupsi dan masalah yang dihadapi dalam penerapan kumulasi sanksi eksternal. Penelitian ini menggunakan metode penelitian normatif untuk menganalisis pertimbangan hakim Pengadilan Negeri Sleman dan pejabat daerah yang berwenang menerapkan sanksi administrasi dalam memutus perkara tindak pidana korupsi dengan ancaman sanksi kumulatif eksternal. Dari penelitian ini ditemukan berbagai hal yang dipertimbangkan oleh hakim mengenai adanya perbuatan melanggar hukum yang melampaui kewenangan, memperkaya diri sendiri atau orang lain dan juga menimbulkan kerugian negara. Pejabat pemerintah yang berwenang mempertimbangkan karena yang bersangkutan telah terbukti secara sah melakukan korupsi. Penerapan sanksi kumulatif eksternal berlawanan dengan asas ultimum remedium, karena pengenaan sanksi administrasi bagi terpidana dikenakan setelah yang bersangkutan dikenakan sanksi pidana.
\end{abstract}

Kata-kata Kunci: Pertimbangan Hukum; Kumulasi Eksternal; Korupsi.

\begin{abstract}
The problem highlighted in this research focuses on different perspectives on legal considerations taken by judges and government officers who have authorities to conduct administrative law enforcement in corruption cases and it also focuses on the existed problems in the implementation of cumulative external punishment. This research uses normative research method to analyze the consideration of the judges of Sleman State Court and Regional Officers who have authorities to implement administrative punishment in eliminating corruption case by using cumulative external punishment. It is found as the result of this research that the judge's considerations observed few matters: the existence of legal violation act which is beyond authority, the intention to enrich particular persons, and the appearance of the State's loss. Meanwhile, the considerations of the authorized government officers concluded that the administrative penalty should be applied to a person who was found guilty in doing corruption. This article stresses that the implementation of external cumulative punishment contradicts the principle of ultimum remidium as the administrative punishment is applied after the convicted is charged with criminal punishment.
\end{abstract}

Keywords: Legal Consideration; External Cummulative; Corruption. 


\section{PENDAHULUAN}

Lahirnya Undang-Undang Nomor 31 Tahun 1999 sebagaimana telah diubah dengan UU No. 20 Tahun 2001 tentang Pemberantasan Tindak Pidana Korupsi (UU Tipikor), diharapkan mampu memenuhi dan mengantisipasi perkembangan kebutuhan hukum masyarakat dalam rangka mencegah dan memberantas secara lebih efektif setiap bentuk tindak pidana korupsi yang sangat merugikan keuangan negara atau perekonomian negara pada khususnya serta masyarakat pada umumnya. UU Tipikor memuat ketentuan pidana yang berbeda dengan UU sebelumnya, yaitu menentukan ancaman pidana minimum khusus, pidana denda yang lebih tinggi, dan ancaman pidana mati yang merupakan pemberatan pidana. Selain itu, UU ini memuat juga pidana penjara bagi pelaku tipikor yang tidak dapat membayar pidana tambahan berupa uang pengganti kerugian negara. UU ini juga memperluas pengertian 'pegawai negeri'.

Menurut Artidjo Alkostar korupsi sebagai extra ordinary crimes. Korupsi politik yang terjadi di Indonesia ditunjukkan dalam berbagai kasus korupsi yang terbukti dilakukan oleh pejabat atau penyelenggara negara. Telah banyak pemangku kekuasaan politik yang dipidana karena melakukan korupsi yang merugikan keuangan negara. Korban kejahatan korupsi politik adalah rakyat. ${ }^{1}$ Apa yang dikatakan oleh Artidjo tersebut mencerminkan bahwa tindak pidana korupsi tidak merupakan tindak pidana yang begitu mudah untuk diberantas. Kerugian yang timbul dari tipikor dan impact sosial yang akan terjadi bila korupsi terjadi haruslah menjadi perhatian dari semua pihak. Meskipun itu sulit diberantas bukan berarti sudah tidak ada jalan keluar. Komparasi dengan melihat pengalaman empiris yang dilakukan oleh negara lain merupakan salah satu hal yang bisa dilakukan. Singapura adalah negara maju yang mana kesadaran masayarakat dan sikap serta budaya profesionalisme sudah mendarah daging. Selain itu komitmen pemerintah Singapura dalam memberantas korupsi sangatlah besar. Hal ini ditunjukkan dengan di Singapura, Perdana Menteri Lee Kwan Yew pada masa awal pemerintahannya mendeklarasikan perang terhadap korupsi dengan jargonnya 'no one, not even top government officials are immuned from investigation and punishment for corruption' (tidak seorang pun, meskipun pejabat tinggi negara yang kebal dari penyelidikan dan hukuman dari tindak korupsi). Apabila kita lihat komitmen yang begitu besar dan cara yang begitu efisien dan efektif yang diterapkan oleh Singapura, rasa-rasanya akan sulit untuk diterapkan di Indonesia. ${ }^{2}$

Romli Atmasasmita mengatakan sebagai berikut:

Aspirasi 250 juta rakyat tentunya bukan monopoli KPK sendirian, melainkan juga menjadi sense of belonging seluruh aparatur hukum termasuk para hakim. Begitu juga

Artidjo Alkostar, 'Korupsi Sebagai Extra Ordinary Crime Dan Tugas Yuridis Para Hakim' (Mahkamah Agung, 28 Mei 2013) <https://bawas.mahkamahagung.go.id/component/conte nt/article/3-artikel-khusus-badan-pengawas/323-korupsi-sebagai-extra-ordinary-crime-dantugas-yuridis-para-hakim> diakses 10 Desember 2019.

2 Tunjung Mahardika Hariadi, 'Perbandingan Penanganan Tindak Pidana Korupsi di Negara Singapura dan Indonesia' (2013) 2 (3) Jurnal Recidive 265, 278. 
aspirasi keadilan jangan hanya dilihat dari kaca mata kepentingan 250 juta rakyat, melainkan juga harus dipertimbangkan rasa keadilan tersangka/terdakwa ketika harus terpaksa dipisahkan dari anak dan istrinya. Janganlah karena perlakuan yang melanggar hukum, status tersangka/ terdakwa berubah menjadi korban perlakuan negara yang tidak luput dari kekeliruan sehingga merupakan abuse of power dan miscarriage of justice. ${ }^{3}$

Korupsi merupakan tindak pidana yang banyak dilakukan oleh aparatur negara. Di dalam konsideran UU No. 28 Tahun 1999 tentang Penyelenggaraan Negara yang Bersih dan Bebas dari Korupsi, Kolusi dan Nepotisme antara lain ditentukan bahwa penyelenggara negara mempunyai peranan yang sangat menentukan dalam penyelenggaraan negara untuk mencapai cita-cita perjuangan bangsa mewujudkan masyarakat yang adil dan makmur sebagaimana tercantum dalam Undang-Undang Dasar Negara Republik Indonesia Tahun 1945. Selanjutnya juga ditentukan bahwa praktek korupsi, kolusi, dan nepotisme (KKN) tidak hanya dilakukan antar penyelenggara negara melainkan juga antara penyelenggara negara dengan pihak lain yang dapat merusak sendisendi kehidupan bermasyarakat, berbangsa, dan bernegara serta membahayakan eksistensi negara, sehingga diperlukan landasan hukum untuk pencegahannya

Pejabat pemerintahan sebagai pejabat publik mempunyai kewenangan tertentu. Oleh karena kewenangan tersebut maka pejabat pemerintahan dapat menyalahgunakan untuk memperkaya diri sendiri atau orang lain sehingga dapat merugikan negara. Apabila hal seperti itu terjadi maka secara yuridis masuk kategori tipikor. Terhadap tindak pidana yang demikian dapat dikenakan sanksi secara kumulatif, yakni sanksi pidana dipadukan dengan pengenaan sanksi administrasi, atau yang dikenal sebagai kumulasi sanksi eksternal. Di sisi lain sebenarnya di dalam aturan UU Tipikor memungkinkan adanya kumulasi sanksi internal, yakni dengan dijatuhkannya lebih dari satu sanksi pidana terhadap pelaku tipikor yang sama. Penjatuhan sanksi dalam tipikor yang berupa kumulasi sanksi eksternal menjadi kewenangan dua instansi yang berbeda, yakni untuk sanksi pidana dijatuhkan oleh pengadilan, sementara untuk sanksi administrasi dijatuhkan oleh badan atau pejabat pemerintahan yang berwenang. Oleh karena itu menarik untuk diketahui mengenai pertimbangan dan mekanisme dalam penerapan sanksi secara kumulatif terhadap tipikor tersebut.

Penelitian ini dilakukan di Kabupaten Sleman dengan pertimbangan bahwa di wilayah Daerah Istimewa Yogyakarta (DIY) merupakan kabupaten yang mempunyai posisi yang penting. Dalam konstelasi DIY, Kabupaten Sleman mengalami pertumbuhan yang pesat dan pekerjaan yang banyak, sehingga mempunyai konsekuensi besarnya potensi penyimpangan penggunaan kewenangan tersebut oleh pejabat yang berwenang. Jenis penelitian ini adalah penelitian hukum normatif, yang berfokus pada norma hukum positif berupa peraturan perundang-

3 Romli Atmasasmita, 'Masalah Krusial Pemberantasan Korupsi di Indonesia' Koran SINDO (6 Oktober 2015) 4. 
undangan. ${ }^{4}$ Menurut Soerjono Soekanto penelitian deskriptif yaitu suatu penelitian yang bertujuan untuk memberikan gambaran atau penjelasan secara konkrit tentang keadaan objek atau masalah yang diteliti tanpa mengambil kesimpulan secara umum. ${ }^{5}$ Dalam hal ini penelitian diarahkan terhadap pertimbangan hukum oleh hakim Pengadilan Negeri Sleman dan pejabat pemerintah yang berwenang dalam memeriksa dan memutus perkara pidana yang berupa tipikor, khususnya pengadaan buku pada tahun 2004/2005 oleh Pemerintah Kabupaten Sleman.

Berdasarkan sifatnya, penelitian ini termasuk dalam penelitian kualitatif yang dimaksudkan untuk menemukan kebenaran kualitatif yakni kesesuaian sesuatu dengan sesuatu yang lain berdasarkan ukuran yang berupa keharusan dipenuhinya persyaratan kualitas (nilai atau sifat) tertentu. ${ }^{6}$ Pendekatan yang digunakan dalam penelitian ini adalah sosiologi hukum dan pendekatan politik hukum.

Data yang dipergunakan dalam penelitian ini adalah data sekunder, yang terdiri atas bahan hukum primer yaitu bahan-bahan hukum yang mengikat berupa peraturan perundang-undangan, bahan hukum sekunder yang memberikan penjelasan mengenai bahan hukum primer yaitu pendapat hukum dan non hukum yang diperoleh dari buku, hasil penelitian, dan makalah. Bahan hukum sekunder juga berupa salinan putusan pengadilan terhadap tipikor, serta salinan keputusan pejabat pemerintah yang berwenang dalam menjatuhkan sanksi administrasi terhadap pelaku tipikor. Selain itu juga didukung oleh pendapat hukum dan pendapat non hukum yang berasal dari para narasumber.

Mendasarkan fenomena yang berkembang seperti itu, maka permasalahan yang diangkat dalam penelitian ini adalah: Pertama, apakah dasar pertimbangan hukum dalam putusan dari hakim Pengadilan Negeri Sleman (PN Sleman) dan pejabat pemerintah yang berwenang dalam penerapan kumulasi sanksi eksternal terhadap pelaku tipikor? Kedua, apakah kendala hakim dan pejabat yang berwenang dalam menerapkan kumulasi sanksi eksternal terhadap pelaku tipikor?

\section{PEMBAHASAN}

\section{Pertimbangan Hukum dalam Putusan dari Hakim PN Sleman dan Pejabat Pemerintah yang Berwenang dalam Penerapan Kumulasi Sanksi Eksternal}

Secara umum mengenai Pegawai Negeri Sipil Daerah Kabupaten Sleman sampai dengan Desember berjumlah 8,906 orang, sebanyak 775 menduduki jabatan struktural, sebanyak 4,578 menduduki jabatan fungsional tertentu di bidang pendidikan, sebanyak 1,304 jabatan fungsional tertentu bidang kesehatan, sebanyak 292 menduduki jabatan fungsional tertentu di bidang teknis, sebanyak 1,957 sebagai jabatan

\footnotetext{
$4 \quad$ Philipus Mandiri Hadjon, 'Pengkajian Ilmu Hukum Dogmatik (Normatif)' (1994) 8 (1) (1994) Jurnal Yuridika FH Unair. Lihat juga Johnny Ibrahim, Teori \& Metodologi Penelitian Hukum Normatif (cet. 3, Bayu Media Publishing 2006) 33; Lihat juga dalam Peter Mahmud Marzuki, Penelitian Hukum (cet. 11, Kencana Prenada Media 2005) 47.

Soerjono Soekanto, Pengantar Penelitian Hukum (UI Press 1981) 10.

F. Sugeng Istanto, Penelitian Hukum (CV.Ganda 2007) 9.
} 
pelaksana. ${ }^{7}$ Sebagian dari PNS Daerah Kabupaten Sleman menduduki jabatan struktural, yakni sebanyak 811 orang. Jabatan struktural berkaitan dengan kewenangan dan fungsi untuk mengelola dan memimpin satuan organisasi pemerintah daerah. Selain PNS tersebut di Kabupaten Sleman juga terdapat pejabat pemerintahan seperti misalnya anggota Dewan Perwakilan Rakyat Daerah (DPRD).

Melihat jumlah pegawai negeri dan pejabat pemerintahan yang ada di Kabupaten Sleman tersebut maka sekaligus dapat dilihat potensi korupsinya. Penanganan korupsi melalui pengadilan merupakan kewenangan hakim untuk menangani dan menyelesaikan. Di dalam memeriksa dan memutus perkara hakim mempunyai pertimbangan tertentu. Hal tersebut dilakukan karena memang secara normatif tidak dibenarkan putusan diambil dengan tidak dilengkapi pertimbangan yang menjadi landasan pengambilan putusan tersebut. Oleh karena itu legal reasoning dari putusan dapat dilihat dalam pertimbangan hukum hakim.

Dalam kaitannya dengan penanganan kasus korupsi di Kabupaten Sleman ada kasus-kasus tertentu yang menyedot perhatian publik sehingga patut untuk dijadikan contoh di dalam penelitian ini. Salah satu contoh kasus tersebut adalah kasus korupsi pengadaan buku pelajaran Sekolah Dasar (SD), Sekolah Menengah Pertama (SMP), Sekolah Menengah Atas (SMA) yang sangat ramai dibicarakan sekitar tahun 20092010 karena melibatkan pejabat penting di lingkungan Pemerintah Kabupaten Sleman. Dalam penelitian ini salinan putusan yang dijadikan objek penelitian adalah putusan PN Sleman No. 534/Pid.B/2008/PN. Slmn terhadap terpidana tipikor Jarot Subiantoro, yang juga melibatkan banyak pihak, oleh karena itu begitu menyedot perhatian masa. Kasus ini menyeret nama terdakwa Jarot Subiantoro, salah satu anggota DPRD Kabupaten Sleman periode tahun 2004-2009. Pihak yang bersangkutan terlibat dalam proyek pengadaan buku SD, SMP, SMA yang ditawarkan oleh PT. Balai Pustaka yang diwakili oleh Murod Irawan, Kepala Dinas Pendidikan Kabupaten Sleman sebesar Rp. 65.353.116.465. Selaku Ketua DPRD dia tidak pernah melaporkan ke Komisi Pemberantasan Korupsi (KPK) tentang adanya uang yang disetorkan melalui rekening terdakwa oleh Murod Irawan sebesar Rp. 1.230.000.000. Dalam pertimbangan hukumnya hakim menilai Terdakwa didakwa melanggar Pasal 2 ayat (1) jo. Pasal 18 UU Tipikor Jo. Pasal 64 ayat (1) Kitab UndangUndang Hukum Pidana. Dalam putusanya, Majelis hakim yang menangani perkara tersebut menyatakan pada intinya:

Menyatakan terdakwa Jarot
Subiyantoro terbukti secara sah dan
meyakinkan melakukan tipikor
secara bersama-sama dan berlanjut.
Menghukum terdakwa dengan
pidana penjara selarna 5 (lima)
tahun dan denda sebesar Rp
200.000 .000 (dua ratus juta rupiah),
dengan ketentuan apabila denda
tersebut tidak dibayar oleh
terdakwa, diganti dcngan pidana
kurungan selama 3 (tiga) bulan.
Menghukum pula terdakwa
membayar uang pengganti sebesar

Menyatakan terdakwa Jarot Subiyantoro terbukti secara sah dan meyakinkan melakukan tipikor secara bersama-sama dan berlanjut. Menghukum terdakwa dengan pidana penjara selarna 5 (lima) tahun dan denda sebesar Rp 200.000.000 (dua ratus juta rupiah), dengan ketentuan apabila denda tersebut tidak dibayar oleh terdakwa, diganti dengan pidana kurungan selama 3 (tiga) bulan. membayar uang pengganti sebesar

7 Anonim, 'Dashboard Pegawai' (Badan Kepegawaian Kabupaten Sleman) <https://bkpp.slemankab.go.id/dashboard-pegawai/> diakses 5 Januari 2020. 
Rp 1.230.050.000 (satu milyar dua ratus tiga puluh juta lima puluh ribu rupiah) dikurangi hasil penjualan rumah yang dirampas, dengan ketentuan jika sisa uang pengganti tersebut tidak dibayar dalam jangka waktu 1 (satu) bulan sesudah putusan ini berkekuatan hukum tetap, maka harta bendanya disita dan jika harta bendanya tidak mencukupi untuk membayar uang penganti tersebut maka di pidana dengan pidana penjara selama 4 (empat) bulan, menetapkan masa penahanan yang telah dijalani oleh terdakwa dikurangkan dari pidana yang dijatuhkan, serta memerintahkan agar terdakwa tetap ditahan.

Dalam putusan tersebut, majelis hakim mempertimbangkan bahwa tindakan terdakwa sebagai ketua DPRD yang membuat dan menandatangani surat keputusan Pimpinan Dewan No. 24/K.PIMP. DPRD/2004 tanggal 21 April 2004 yang memberi persetujuan menunjuk secara langsung tanpa melalui lelang pengadaan buku teks wajib SD/MI sudah merupakan perbuatan melawan hukum, karena hal tersebut bertentangan dengan Keputusan Presiden No. 8 Tahun 2003 tentang Pedoman Pelaksanaan Pengadaan Barang/Jasa Pemerintah (Kepres No. 8 Tahun 2003) khususnya Pasal 17 ayat (1) yang menyatakan bahwa 'dalam pemilihan penyedia barang/ jasa, pemborongan, jasa lainnya pada prinsipnya dilakukan melalui metode pelelangan.' Majelis hakim juga mempertimbangkan ketentuan dalam Pasal 9 ayat (3) Kepres ini menentukan kewenangan menetapkan perencanaan pengadaan (termasuk penetapan metoda pemilihan penyedia barang/ jasa: lelang umum atau penunjukan langsung menjadi kewenangan pengguna barang/jasa yaitu pimpro/ kepala kantor. Begitu pula dalam Pasal 5 yang menentukan bahwa para pihak terkait dilarang mengintervensi/ mencampuri/ mempengaruhi dan harus mencegah penyalahgunaan wewenang yang bertujuan untuk berkolusi. Dari rangkaian ketentuan tersebut maka Ketua DPRD tidaklah berwenang menetapkan metode penunjukan langsung, karena bertentangan dengan Kepres ini. Jadi seharusnya terdakwa selaku Ketua DPRD menolak permohonan usulan Bupati tentang penunjukan langsung kepada PT. Balai Pustaka, karena tugas dan fungsi DPRD adalah fungsi/tugas legislasi, fungsi/tugas anggaran dan fungsi/tugas pengawasan. Dengan demikian majelis hakim berpendapat bahwa unsur melawan hukum telah terpenuhi dan terbukti. Hakim mempertimbangkan bahwa berdasarkan uraian di atas maka menurut majelis hakim unsur melakukan perbuatan memperkaya diri sendiri, orang lain atau suatu korporasi telah terpenuhi. Sumber dana dari proyek pengadaan buku tersebut berasal dari pemerintah daerah yaitu Anggaran Pendapatan dan Belanja Daerah (APBD) tahun anggaran 2004 dan tahun anggaran 2005. Dari uraian pertimbangan tersebut, majelis hakim berpendapat bahwa unsur dapat merugikan keuangan negara atau perekonomian negara telah terpenuhi dan terbukti.

Di samping pertimbangan tersebut, majelis hakim juga mempertimbangkan hal-hal yang meringankan dan memberatkan. Hal-hal yang memberatkan bahwa perbuatan terdakwa bertentangan dengan semangat bangsa dan negara dalam pemberantasan tipikor. Perbuatan terdakwa melukai hati masyarakat khususnya dunia pendidikan di kabupaten Sleman. Terdakwa selaku Ketua DPRD ataupun selaku anggota 
DPRD Kabupaten Sleman tidak menjalankan fungsi pengawasan dengan baik, dan pemah dihukum dalam perkara narkoba. Hal-hal yang meringankan terdakwa berterus terang atas perbuatannya, bersikap sopan di persidangan, mengaku bersalah dan menyesali perbuatannya, serta mempunyai tanggungan keluarga isteri dan anak.

Menurut pendapat ahli yang dimintai keteranganya dalam pemeriksaan di pengadilan, Muchsan bahwa:

Apabila dapat dibuktikan perbuatan hukum yang benar menurut hukum administrasi tersebut mempunyai implikasi terhadap perbuatan hukum pidana, maka pejabat yang bersangkutan harus bertanggung jawab secara pidana. Secara teori hukum pidana berada di atas hukum administrasi dan hukum perdata. Dengan demikian walaupun perbuatan terdakwa membuat surat kepada DPRD untuk meminta persetujuan anggaran dan pengadaan barang dengan penunjukan langsung, mengeluarkan surat kepada kepala dinas tentang izin penunjukan langsung, membuat disposisi tentang cashbon adalah perbuatan dalam hukum administrasi, tetapi apabila perbuatan yang secara hukum administrasi terbukti mempunyai dampak pada pelanggaran hukum pidana, dan unsur tindak pidana tersebut dapat dibuktikan jaksa penuntut umum, terdakwa dapat dinyatakan melakukan tindakan melawan hukum pidana, dan harus bertanggung jawab atas perbuatannya. ${ }^{8}$

Demikian juga dengan pendapat ahli Mudzakir apabila pejabat yang melakukan perbuatan administrasi dan mengakibatkan perbuatan pidana maka pejabat tadi harus bertanggung jawab dalam hal administrasi negara dan perbuatan pidana. Penunjukan secara langsung yang tidak sesuai dengan aturan adalah salah dan merupakan perbuatan melawan hukum. Penunjukan langsung yang demikian adalah menyalahgunakan hukum administrasi yang berakibat hukum pidana.

Peneliti sependapat dengan para ahli bahwa perbuatan terdakwa memenuhi unsur melawan hukum seperti penjelasan Pasal 2 ayat (1) UU Tipikor, yang mencakup perbuatan melawan hukum dalam arti formil maupun materiil yaitu meskipun perbuatan tersebut tidak diatur dalam suatu peraturan perundangundangan namun apabila perbuatan tersebut dianggap tercela karena tidak sesuai dengan rasa keadilan atau norma kehidupan sosial dalam masyarakat maka perbuatan tersebut dapat dipidana.

Kasus tersebut juga melibatkan mantan Bupati Sleman, Ibnu Subiyanto. Konsekuensi dari putusan pengadilan yang menjatuhkan pidana penjara selama 4 tahun pada Ibnu Subianto yang terbukti melakukan tipikor, maka yang bersangkutan dinonaktifkan sebagai Bupati Sleman berdasarkan Surat Keputusan Menteri Dalam Negeri Nomor 131.34-485 tahun 2009 yang ditandatangani Menteri Dalam Negeri Mardianto tanggal 19 Juni 2009. Demikian juga putusan hakim terhadap terdakwa FX. Sumpono, selaku Kepala Desa Desa Sendangsari Kecamatan Minggir, Kabupaten Sleman, yang diberhentikan sebagai kepala desa oleh Bupati Sleman, setelah divonis pidana penjara selama 1 tahun karena terbukti melakukan tipikor.

Keputusan senada berlaku juga terhadap Jarot yang tidak hanya

8 Jarot Subiantoro, No. 271/Pid.B/2008/PN.SLMN, Pengadilan Negeri Sleman. 
dikenakan sanksi pidana penjara melainkan juga dikenakan sanksi administrasi berupa pemberhentian sebagai anggota DPRD Kabupaten Sleman berdasarkan Surat Keputusan Gubernur DIY No. 131/KEP/2008. Bahkan juga sanksi politik dari Ketua Dewan Pimpinan Pusat Partai Demokrasi Indonesia Perjuangan (PDIP) yang tertuang dalam Surat Keputusan No. 134/KPTS/DPP/VI/ 2007 tentang pembebastugasan Jarot Subiantoro dari jabatannya sebagai Ketua Pengurus Anak Cabang PDIP Kecamatan Kalasan, Kabupaten Sleman sekaligus anggota DPRD Kabupaten Sleman.

Dalam menangani kasus-kasus KKN sosok figur seorang hakim yang memiliki integritas harus lebih diutamakan. Hal tersebut oleh Suparman dikatakan bahwa seorang hakim sebagai salah satu unsur penyelenggara negara sangat memainkan peran sentral dalam menentukan dapat atau tidaknya seseorang terdakwa kasus KKN dijatuhi pidana sesuai dengan aturan yang berlaku sebagaimana dikehendaki oleh seluruh rakyat Indonesia. ${ }^{9}$ Hakim yang mempunyai integritas tidak hanya mempunyai pemahaman dan kemampuan intelektual, akan tetapi mempunyai kepribadian yang utuh.

Menurut Muhammad Zulfadli dalam kaitan dengan penegakan hukum, yang dimaksud dengan integritas adalah berkaitan dengan integritas aparatur penegak hukum. Aparatur penegak hukum mencakup pengertian mengenai institusi penegak hukum dan aparat (orang) penegak hukum. Dalam arti sempit, aparatur penegak hukum yang terlibat dalam proses tegaknya hukum itu, dimulai dari polisi, penasehat hukum, jaksa, hakim, dan petugas sipir pemasyarakatan. Setiap aparat dan aparatur terkait mencakup pula pihak-pihak yang bersangkutan dengan tugas atau perannya, yaitu terkait dengan kegiatan pelaporan atau pengaduan, penyelidikan, penyidikan, penuntutan, pembuktian, penjatuhan vonis dan pemberian sanksi, serta upaya pemasyarakatan kembali (resosialisai) terpidana. 10

Posisi dan peran penegak hukum yang begitu penting tersebut juga disampaikan oleh Arliman. Menurutnya Penegakan hukum itu sendiri tidak terlepas dari peran serta dari penegak hukum, karena penegak hukumlah yang nantinya menegakkan aturan hukum tersebut. Apabila penegak hukum mempunyai mental yang bobrok maka akan menciptakan penegakan hukum yang bobrok pula, begitu pula sebaliknya apabila penegak hukum mempunyai mental yang baik dalam menjalankan/ menegagkan aturan hukum maka akan menciptakan penegakan hukum yang baik dan bersifat responsif. ${ }^{11}$ Mengingat begitu penting dan strategisnya peran dari aparatur penegak hukum, maka sudah

9 Eman Suparman, 'Menolak Mafia Peradilan: Menjaga Integritas Hakim-Menyelaraskan Perbuatan (2017) 47 (1) Jurnal Hukum \& Pembangunan 61, 67.

10 Muhammad Zulfadli, Kasman Abdullah, Fuad Nur, 'Penegakan Hukum yang Responsif dan Berkeadilan Sebagai Instrumen Perubahan Sosial Untuk Membentuk Karakter Bangsa' (Seminar Nasional "Pendidikan Ilmu-Ilmu Sosial Membentuk Karakter Bangsa Dalam Rangka Daya Saing Global" Kerjasama: Fakultas Ilmu Sosial Universitas Negeri Makassar dan Himpunan Sarjana Pendidikan Ilmu-ilmu Sosial Indonesia, Makassar, 29 Oktober 2016).

11 Laurensius Arliman S, Mewujudkan Penegakan Hukum yang Baik di Negara Hukum Indonesia (2019) 11 (1) Jurnal Dialogia Iuridica 1, 11. 
sepantasnya mereka dilengkapi dengan persyaratan yang dapat mendukung dan menjamin dalam mengemban tugasnya. Integritas tidak hanya bicara soal kejujuran, tetapi integritas berarti menyeluruh (integral).

Dari sisi hukum administrasi, yakni penjatuhan sanksi administrasi, maka dapat dilihat dari bagaimana para terdakwa dikenakan sanksi baik berupa pencabutan hak politik maupun pemberhentian sebagai PNS ataupun pejabat negara. Tidak begitu mudah untuk mendapatkan informasi secara utuh dalam bentuk tertulis mengenai hal ini, akan tetapi berdasarkan informasi yang berkembang melalui media masa maka informasi tersebut dapat diperoleh. Dalam putusan PN Sleman maupun pejabat yang berwenang tidak secara spesifik mencantumkan pertimbangan mengenai penerapan sanksi kumulatif internal maupun eksternal, akan tetapi semangat menegakkan keadilan dan perjuangan membela masa depan bangsa terlihat di sana.

Sesuai dengan terjadinya perkara, pada waktu kasus pengadaan buku tersebut berlaku UU No. 32 Tahun 2004 tentang Pemerintahan Daerah (UU Pemerintahan Daerah). Di dalam Pasal 30 dan 31 UU Pemerintahan Daerah ditentukan:

Pasal 30

(1) Kepala daerah dan/atau wakil kepala daerah diberhentikan sementara oleh Presiden tanpa melalui usulan DPRD apabila dinyatakan melakukan tindak pidana kejahatan yang diancam dengan pidana penjara paling singkat 5 (lima) tahun atau lebih berdasarkan putusan pengadilan;
(2) Kepala daerah dan/atau wakil kepala daerah diberhentikan oleh Presiden tanpa melalui usulan DPRD apabila terbukti melakukan tindak pidana sebagaimana dimaksud pada, ayat (1) berdasarkan putusan pengadilan yang telah memperoleh kekuatan hukum tetap.

Pasal 31

(1) Kepala daerah dan/atau wakil kepala daerah diberhentikan sementara oleh Presiden tanpa melalui usulan DPRD karena didakwa melakukan tipikor, tindak pidana terorisme, makar, dan/atau tindak pidana terhadap keamanan negara.

Ketentuan dalam Pasal 30 ayat (1) dan (2) serta Pasal 31 ayat (1) tersebut menarik bila diterapkan untuk kasus korupsi. Apabila seorang kepala daerah/wakil kepala daerah didakwa melakukan tipikor maka kepadanya dapat diterapkan Pasal 31 ayat (1) yakni diberhentikan sementara oleh Presiden tanpa melalui usulan DPRD. Bila nanti telah ditetapkan melakukan korupsi berdasarkan putusan pengadilan yang berkekuatan hukum tetap maka yang bersangkutan dapat dikenakan pemberhentian oleh Presiden tanpa usulan DPRD sebagaimana ditentukan oleh Pasal 30 ayat (2). Pasal 31 ayat (1) secara eksplisit menyebut tipikor, sementara Pasal 30 ayat (1) tidak menyebut secara eksplisit mengenai tipikor, sehingga bisa diberlakukan bagi tindak pidana lain sepanjang ancaman hukumannya paling singkat 5 tahun penjara. Ketentuan tersebut diterapkan untuk Ibnu Subiyanto sebagai Bupati Sleman. Oleh karena itu pertimbangan ketika mengenakan sanksi administrasi, berupa pemberhentian adalah adanya putusan pengadilan pidana 
yang telah memperoleh kekuatan hukum tetap.

Untuk terdakwa Jarot Subiyantoro diterapkan ketentuan Pasal 55 ayat (2) huruf $f$ UU Pemerintah daerah yang menentukan bahwa anggota DPRD diberhentikan antar waktu, karena dinyatakan bersalah berdasarkan putusan pengadilan yang telah memperoleh kekuatan hukum tetap karena melanggar tindak pidana dengan ancaman pidana paling singkat 5 (lima) tahun penjara atau lebih.

Pasal 378 ayat (3) UU No. 27 Tahun 2009 tentang Majelis Permusyawaratan Rakyat, Dewan Perwakilan Rakyat, Dewan Perwakilan Daerah, dan Dewan Perwakilan Rakyat Daerah (UU MD3) menentukan anggota DPRD kabupaten/kota dilarang melakukan KKN serta dilarang menerima gratifikasi. Konsekuensi dari larangan tersebut diatur dalam Pasal 379 ayat (3), yakni bahwa anggota DPRD kabupaten/kota yang dinyatakan terbukti melanggar larangan tersebut berdasarkan putusan pengadilan yang telah memperoleh kekuatan hukum tetap dikenai sanksi pemberhentian sebagai anggota DPRD kabupaten/kota.

Dengan mendasarkan pada ketentuan tersebut maka penjatuhan sanksi administrasi baik sebagai bupati maupun anggota DPRD didasarkan pada pertimbangan bahwa yang bersangkutan telah terbukti secara sah dan meyakinkan melakukan tipikor berdasarkan putusan pengadilan yang telah berkekuatan hukum tetap. Penjatuhan sanksi administrasi menggunakan tindak pidana sebagai pertimbangannya. Artinya bahwa pejabat yang menjatuhkan sanksi administrasi baru menjatuhkan sanksi itu karena telah ada putusan pengadilan yang berkekuatan hukum tetap, yang menyatakan bahwa yang bersangkutan melakukan tipikor.

Dalam praktek yang terjadi di tanah air memang cukup banyak penerapan sanksi kumulatif eksternal tersebut baik berupa penjatuhan pidana dan sekaligus dibarengi sanksi administrasi yang dapat berupa pencabutan hak politik, pemberhentian sebagai pegawai negeri, maupun sanksi administratif lain. Menarik apabila hal tersebut menjadi sebagai sebuah bukti keseriusan di dalam menyelesaikan masalah korupsi, sehingga selain sanksi pidana yang bersifat condemnatoir (memberi nestapa) juga ada pemberatan sanksi administrasi yang bersifat reparatoir (memperbaiki perilaku).

Penegakan hukum administrasi merupakan penegakan hukum yang begitu khas. Penegakan hukum administrasi (handhaving van het bestuursrecht) merupakan bagian dari "bestuuren". Penegakan hukum administrasi merupakan bagian dari kewenangan pemerintahan. ${ }^{12}$ Sementara menurut P. de Haan, penegakan hukum administrasi diartikan sebagai penerapan sanksi administrasi.13 Berdasarkan pendapat tersebut dapat dipahami bahwa kewenangan penegakan hukum administrasi itu merupakan kewenangan organ pemerintah. ${ }^{14}$ Penegakan hukum

12 H. D. van Wijk \& Willem Konijnenbelt, Hoofdstukken van Administratief Recht (cet. 6, Gravenhage 1984) 281.

13 P. de Haan, et.al., Bestuursrecht in de Sociale Rechtsstaat (Kluwer Deventer 1986) 91.

14 Sri Pudyatmoko Y., Perizinan, Problem dan Upaya Pembenahan (PT.Grasindo 2009) 115-116. 
administrasi tidak melalui proses peradilan, melainkan dapat dikenakan secara langsung.

Tidak ada larangan untuk menerapkan sanksi administrasi bersama dengan sanksi pidana. Dalam hal ini asas ne bis in idem tidak berlaku karena antara sanksi administrasi dan sanksi pidana terdapat perbedaan, baik dalam sifat maupun tujuan. Akan tetapi untuk itu perlu dipenuhi persyaratan bahwa tindakan yang berupa pelanggaran atau kesalahan itu harus memenuhi kualifikasi sebagai perbuatan pidana. Sebab sesuai dengan asas legalitas, maka yang dapat dikenakan sanksi pidana hanyalah tindak pidana yang telah ditentukan sebelumnya menurut UU yang berlaku. ${ }^{15}$

Dalam peraturan perundangundangan menurut Wencislaus terdapat kesamaan persepsi terhadap kejahatan korupsi sebagai kejahatan luar biasa yang berdampak meluas dan sistematis karena merupakan pelanggaran terhadap hak-hak sosial dan hak-hak ekonomi masyarakat. Oleh karena itu dalam upaya penanganan, baik itu pencegahan maupun pemberantasannya tidak lagi dapat dilakukan secara biasa, tetapi harus dengan cara-cara yang luar biasa. ${ }^{16}$ Sejalan dengan hal tersebut maka para penegak hukum mesti berpandangan jauh ke depan, tidak hanya sekedar mengikuti hal-hal yang biasa terjadi dalam penegakan hukum.

\section{Kendala Hakim dan Pejabat yang Berwenang dalam Menerapkan Kumulasi Sanksi Eksternal Terhadap Pelaku Tindak Pidana Korupsi}

Kasus korupsi pengadaan buku sekolah yang terjadi di Kabupaten Sleman yang diangkat dalam tulisan ini terjadi sekitar tahun 2004/2005. Oleh karena itu penanganan perkara korupsinya juga didasarkan pada ketentuan yang berlaku pada waktu itu.

Di dalam UU Pemerintahan Daerah ditentukan:

Pasal 30

(1) Kepala daerah dan/atau wakil kepala daerah diberhentikan sementara oleh Presiden tanpa melalui usulan DPRD apabila dinyatakan melakukan tindak pidana kejahatan yang diancam dengan pidana penjara paling singkat 5 (lima) tahun atau lebih berdasarkan putusan pengadilan;

(2) Kepala daerah dan/atau wakil kepala daerah diberhentikan oleh Presiden tanpa melalui usulan DPRD apabila terbukti melakukan tindak pidana sebagaimana dimaksud pada, ayat (1) berdasarkan putusan pengadilan yang telah memperoleh kekuatan hukum tetap.

Pasal 31

(1) Kepala daerah dan/atau wakil kepala daerah diberhentikan sementara oleh Presiden tanpa melalui usulan DPRD karena didakwa melakukan tipikor, tindak pidana terorisme, makar, dan/atau tindak pidana terhadap keamanan negara.

(2) Kepala daerah dan/atau wakil kepala daerah diberhentikan

\footnotetext{
15 Sri Pudyatmoko Y., Penegakan dan Perlindungan Hukum di Bidang Pajak (PT. Salemba Empat 2007) 15-16.

16 Wencislaus Sirjon Nansi, 'Gagasan Reformasi Kebijakan Pemasyarakatan Narapidana Korupsi Dalam Upaya Mencegah Praktek Korupsi Pada Lembaga Pemasyarakatan’ (2018) 34 (2) Jurnal Justitia et Paxb 223, 235.
} 
oleh Presiden tanpa melalui usulan DPRD karena terbukti melakukan makar dan/atau perbuatan lain yang dapat memecah belah Negara Kesatuan Republik Indonesia yang dinyatakan dengan putusan pengadilan yang telah memperoleh kekuatan hukum tetap.

Ketentuan dalam Pasal 30 ayat (1) dan (2) serta Pasal 31 ayat (1) dan (2) tersebut menarik bila diterapkan untuk kasus korupsi. Apabila seorang kepala daerah/wakil kepala daerah didakwa melakukan tipikor maka kepadanya dapat diterapkan Pasal 31 ayat (1) yakni diberhentikan sementara oleh Presiden tanpa melalui usulan DPRD. Bila nanti telah ditetapkan melakukan korupsi berdasarkan putusan pengadilan yang berkekuatan hukum tetap maka yang bersangkutan dapat dikenakan pemberhentian oleh Presiden tanpa usulan DPRD. Pasal 31 ayat (1) secara eksplisit menyebut tipikor, sementara Pasal 30 ayat (1) tidak menyebut secara eksplisit mengenai tipikor, sehingga bisa diberlakukan bagi tindak pidana lain sepanjang ancaman hukumannya paling singkat 5 tahun penjara.

Ketentuan tersebut diterapkan untuk tipikor yang dilakukan oleh seorang kepala daerah/wakil kepala daerah. Dalam ketentuan tersebut pengenaan sanksi administrasi dimulai dari pemberhentian sementara ketika seorang kepala daerah/wakil kepala daerah menjadi tersangka tindak pidana. Setelah yang bersangkutan dinyatakan bersalah berdasarkan putusan pengadilan yang telah berkekuatan hukum tetap, maka yang bersangkutan dapat dikenakan sanksi administrasi berupa pemberhentian tanpa usulan DPRD. Hal yang menarik di sini adalah penjatuhan sanksi administrasi baik pemberhentian sementara maupun pemberhentian dari jabatan kepala daerah/ wakil kepala daerah itu semuanya didahului dengan proses penanganan perkara pidana, yakni berupa penetapan sebagai tersangka maupun penetapan sebagai pelaku tindak pidana berdasarkan putusan pengadilan yang berkekuatan hukum tetap. Artinya di sini sanksi administrasi mengikuti proses pidana.

Untuk tipikor yang dilakukan oleh anggota DPRD, ditaur dalam Pasal 55 ayat (2), (3), (4) dan (5) UU Pemerintahan Daerah yang menentukan sebagai berikut:

(2) Anggota DPRD diberhentikan antar waktu, karena:

a. tidak dapat melaksanakan tugas secara berkelanjutan atau berhalangan tetap secara berturut-turut selama 6 (enam) bulan;

b. tidak lagi memenuhi syarat sebagai anggota DPRD;

c. dinyatakan melanggar sumpah/janji jabatan, dan/atau melanggar kode etik DPRD;

d. tidak melaksanakan kewajiban anggota DPRD;

e. melanggar larangan bagi anggota DPRD;

f. dinyatakan bersalah berdasarkan putusan pengadilan yang telah memperoleh kekuatan hukum tetap karena melanggar tindak pidana dengan ancaman pidana paling singkat 5 (lima) tahun penjara atau lebih.

(3) Pemberhentian anggota DPRD yang telah memenuhi ketentuan sebagaimana dimaksud pada ayat (1) dan ayat (2) disampaikan oleh Pimpinan DPRD kepada Menteri Dalam Negeri melalui Gubernur bagi 
anggota DPRD provinsi dan kepada Gubernur melalui Bupati/Walikota bagi anggota DPRD kabupaten/kota untuk diresmikan pemberhentiannya.

(4) Pemberhentian anggota DPRD sebagaimana dimaksud pada ayat (2) huruf a, huruf b, huruf $c$, huruf $d$, dan huruf $e$ dilaksanakan setelah ada keputusan DPRD berdasarkan rekomendasi dari Badan Kehormatan DPRD.

(5) Pelaksanaan ketentuan sebagaimana dimaksud pada ayat (1), ayat (2), ayat (3), dan ayat (4) diatur dalam Peraturan Tata Tertib DPRD berpedoman pada peraturan perundangundangan.

Pasal 378 ayat (3) UU MD3 menyebutkan bahwa anggota DPRD kabupaten/kota dilarang melakukan KKN serta dilarang menerima gratifikasi. Konsekuensi dari larangan tersebut diatur dalam Pasal 379 ayat (3), yakni bahwa anggota DPRD kabupaten/kota yang dinyatakan terbukti melanggar larangan tersebut berdasarkan putusan pengadilan yang telah memperoleh kekuatan hukum tetap dikenai sanksi pemberhentian sebagai anggota DPRD kabupaten/ kota.

Ketentuan yang tercantum dalam UU Pemerintahan Daerah dan UU MD3 tersebut sama-sama menentukan mengenai pengenaan sanksi administrasi bagi anggota DPRD yang melakukan pelanggaran. Di dalam UU Pemerintahan Daerah disebutkan sebagai pemberhentian antar waktu anggota Dewan, dan di UU MD3 disebut sebagai pemberhentian sebagai anggota DPRD.

Penegakan hukum pidana berbeda dengan penegakan hukum administrasi. Penegakan hukum pidana dilakukan dengan melalui proses peradilan, dan dilakukan dengan menerapkan sanksi pidana. Dalam literatur hukum pidana dipahami bahwa sanksi pidana merupakan sanksi yang diterapkan apabila sanksi yang lain tidak efektif untuk diterapkan. Dalam bahasa hukum sering disebut sebagai ultimum remedium. Hal tersebut disebabkan karena sanksi pidana bersifat keras dan memberikan nestapa (condemnatoir).

Menurut Van Bemmelen sebagaimana dikutip Andi Zainal mengatakan bahwa alasan pengenaan sanksi pidana berupa penderitaan yang menjadikan hukum pidana digunakan sebagai upaya terakhir (ultimum remedium) guna memperbaiki tingkah laku manusia terutama pelaku kejahatan (penjahat), serta memberikan tekanan psikologis agar orang lain tidak melakukan kejahatan. ${ }^{17}$ Berbeda dengan sanksi administrasi yang bersifat reparatoir, di mana orientasi dari pengenaan sanksi administrasi adalah bagaimana perilaku yang salah itu diperbaiki (reparasi), sanksi pidana terlihat lebih menekankan pada nestapa dan tidak hanya memberi efek jera kepada si pelaku tetapi juga orang lain yang akan melakukan hal yang sama.

Sudikno Mertokusumo mengatakan bahwa ultimum remedium merupakan salah satu asas yang terdapat di dalam hukum pidana Indonesia yang mengatakan hukum pidana hendaklah dijadikan upaya terakhir dalam penegakan hukum. ${ }^{18}$ Pendapat serupa disampakan oleh Wirjono Prodjodikoro yakni bahwa

$17 \quad$ Andi Zainal Abidin, Asas-asas Hukum Pidana Bagian Pertama (Alumni 1987) 16.

18 Sudikno Mertokusumo, Penemuan Hukum Sebuah Pengantar (cet. 3, Liberty 2006) 128. 
norma-norma atau kaidah-kaidah dalam bidang hukum tata negara dan hukum tata usaha negara harus pertama-tama ditanggapi dengan sanksi administrasi, begitu pula norma-norma dalam bidang hukum perdata pertama-tama harus ditanggapi dengan sanksi perdata. Hanya, apabila sanksi administrasi dan sanksi perdata ini belum mencukupi untuk mencapai tujuan meluruskan neraca kemasyarakatan, maka baru diadakan juga sanksi pidana sebagai pamungkas (terakhir) atau ultimum remedium. ${ }^{19}$ Dari beberapa pendapat tersebut maka dapat dipahami bahwa pola dalam penerapan sanksi penegakan hukum dikenakan dengan menerapkan sanksi perdata dan sanksi administrasi terlebih dahulu. Sanksi pidana diterapkan manakala sanksi perdata dan sanksi administrasi sudah diterapkan akan tetapi ternyata belum efektif untuk mengatasi pelanggaran.

Penggunaan sanksi pidana mendahului sanksi yang lain menjadikan asas ultimum remedium bergeser menjadi primum remidium. $\mathrm{H}$. G. de Bunt dalam bukunya strafrechtelijke handhaving van miliue recht sebagaimana dikutip Romli Atmasasmita mengatakan bahwa hukum pidana dapat menjadi primum remidium jika korban sangat besar, tersangka/terdakwa merupakan recidivist, dan kerugian tidak dapat dipulihkan (irreparable). ${ }^{20}$ Korupsi memang dapat menimbulkan kerugian yang begitu besar, akan tetapi korbannya terutama bukan kepentingan orang-perorangan. Korupsi dapat membawa korban berupa kerugian materiil yang kemungkinan bisa dipulihkan, akan tetapi kerugian yang lain belum tentu dapat dipulihkan dengan baik.

Bila mendasarkan pada aturan yang telah diuraikan maka di situ terlihat bahwa pembentuk UU mendasarkan penjatuhan sanksi administrasi berupa pemberhentian dari jabatan bagi anggota DPRD kabupaten/kota dan juga bagi bupati/walikota pada sanksi pidana. Artinya memang sanksi administrasi baru bisa dikenakan ketika sudah ada kepastian mengenai tindak pidananya. Dari sisi asas ultimum remedium ini tentu menjadi sesuatu yang berlawanan, akan tetapi nampaknya pembentuk UU lebih menekankan pada sisi keadilan. Seorang bupati/ walikota dan anggota DPRD yang telah diberhentikan karena sanksi tentu akan membawa konsekuensi baik bagi pejabat yang bersangkutan maupun terhadap jabatan yang ditinggalkannya. Dari sisi pejabat tersebut maka tentu akan kehilangan hak-hak sehubungan dengan jabatan tersebut dan dibebaskan dari kewajibannya. Dari sisi jabatan yang ditinggalkan, maka tugas dan tanggung jawab dari jabatan tersebut tidak lagi pejabat yang bersangkutan yang menangani. Bisa jadi akan menjadi tidak adil bila yang bersangkutan diberhentikan dari jabatannya terlebih dahulu lalu baru perkara pidananya diproses. Hal tersebut terjadi karena selama penanganan perkara pidana tersebut sebenarnya secara hukum, orang yang bersangkutan belum tentu bersalah. Kesalahan itu baru pasti secara hukum bersalah bila nanti sudah

\footnotetext{
19 Wirjono Prodjodikoro, Asas-Asas Hukum Pidana di Indonesia (cet. 3, Refika Aditama 2003$) 17$.

20 H. G. de Bunt, Strafrechtelijke Handhaving Van Miliue Recht 1989) dalam Romli Atmasasmita, Globalisasi dan Kejahatan Bisnis (Kencana Prenada Media Group 2010) 192.
} 
diputuskan oleh pengadilan dan putusannya itu mempunyai kekuatan hukum tetap. Proses penanganan perkara pidana tidak selalu berjalan dalam waktu yang cepat, bisa saja itu berlangsung begitu lama. Apabila hal seperti itu terjadi dan yang bersangkutan sudah diberhentikan dari jabatannya, maka tentu akan bisa sangat merugikan terhadap yang bersangkutan. Pembentuk UU bisa jadi lebih menekankan asas keadilan dan kepastian hukum dengan mengesampingkan asas ultimum remedium.

Menurut Primus dan Aloysius terdapat fenomena dalam penegakan hukum semata-mata mengutamakan unsur kepastian hukum dengan mengabaikan rasa keadilan masyarakat. Cara pandang (worldview) penegak hukum pada umumnya meyakini bahwa hukum positif (peraturan perundang-undangan) merupakan sumber hukum yang paripurna dan harus dijalankan apa adanya (tekstual). Padalah peraturan perundang-undangan merupakan produk politik dan politik adalah kepentingan. Pada negara yang sistem demokrasinya masih ditandai dengan biaya politik yang tinggi maka pada umumnya partisipasi publik sulit mengakses pada proses penyusunan peraturan perundang-undangan sehingga hasil produk legislatif lebih mengakomodasi kepentingan elit tertentu. ${ }^{21}$ Kesadaran seperti itu dapat membawa pemahaman bahwa aturan hukum tidak harus dipahami sebagai acuan tunggal yang sepenuhnya sebagai dasar sempurna dalam penanganan perkara.
Sudikno Mertokusumo berpendapat bahwa hukum yang berfungsi sebagai perlindungan kepentingan manusia dalam penegakannya harus memperhatikan 3 (tiga) unsur fundamental hukum, antara lain: kepastian hukum (Rechtssicherheit), kemanfaatan (Zweckmassigkeit) dan keadilan (Gerechtigkeit). Oleh karena itu, dalam menentukan pemberian sanksi pidana dalam suatu UU perlu memperhatikan ketiga unsur fundamental hukum tersebut karena pada dasarnya itulah yang menjadi hakikat dari tujuan hukum. ${ }^{22}$

Dalam kumulasi sanksi administrasi dibarengkan dengan sanksi pidana seperti tersebut di atas, nampaknya kepastian hukum dan keadilan lebih menonjol. Kepastian hukum yang ditunjukkan dengan adanya putusan pengadilan yang telah berkekuatan hukum tetap bahwa orang tersebut telah dinyatakan bersalah, dan sekaligus adil karena memberikan pemberatan dengan pengenaan sanksi administrasi. Akan tetapi sekaligus pada saat yang bersamaan terjadi pertentangan dengan asas ultimum remedium terhadap perkara pidana. Kiranya menjadi persoalan yang dipertimbangkan andaikata dituruti asas ultimum remedium, yang menerapkan sanksi pidana setelah sanksi administrasi. Hal itu terjadi misalnya pejabat tersebut telah dikenakan sanksi pemberhentian dari jabatannya, dan baru diproses peradilan pidananya dan ternyata yang bersangkutan dinyatakan tidak bersalah. Padahal yang bersangkutan telah dikenakan pemberhentian dari jabatan, yang

21 Primus Adiodatus Abi Bartama dan Aloysius Wisnubroto, 'Urgensi Perubahan Paradigma Penegakan Hukum dalam Menghadapi Tantangan Era Kontemporer (2017) 33 (1) Jurnal Justitia et Pax 39, 46.

22 Sudikno Mertokusumo, Mengenal Hukum Suatu Pengantar (Liberty 2007) 160. 
berarti juga ada konsekuensi hak-hak yang melekat pada jabatan itu.

Asas ultimum remedium mengandaikan bahwa sanksi pidana bersifat keras, dan berbeda dengan sanksi lain seperti sanksi perdata dan sanksi administrasi. Padahal sesungguhnya di dalam sanksi pidana sendiri ada sanksi yang ringan, seperti denda, uang pengganti dan sebagainya. Demikian sebaliknya, sanksi administrasi yang dikonotasikan sebagai bersifat ringan, lunak, dan sebagainya juga tidak sepenuhnya benar, karena ada juga yang demikian berat seperti pemberhentian dengan tidak hormat dari suatu jabatan. Untuk itu hakim maupun pejabat yang berwenang mesti memperhatikan tingkat kesalahan dengan menggunakan asas proporsionalitas.

Menurut Hikmahanto Juwana, problem dalam penegakan hukum meliputi sejumlah hal: ${ }^{23}$

(1) Problem pembuatan peraturan perundang-undangan.

(2) Masyarakat pencari kemenangan bukan keadilan.

(3) Uang mewarnai penegakan hukum.

(4) Penegakan hukum sebagai komoditas politik.

(5) Penegakan hukum yang diskriminatif dan ewuh pekewuh.

(6) Lemahnya sumberdaya manusia.

(7) Advokat tahu hukum versus advokat tahu koneksi.

(8) Keterbatasan anggaran.

(9) Penegakan hukum yang dipicu oleh media masa.
Khususnya terhadap penerapan kumulasi sanksi yang dikenakan terhadap pelaku tipikor dalam kasus di Kabupaten Sleman tersebut, maka kiranya masuk pada persoalan yang pertama, yakni problem pembuatan peraturan perundang-undangan. Di satu sisi pembentuk UU dituntut untuk memberikan keadilan dan kepastian hukum, akan tetapi di sisi lain mestinya tidak boleh menabrak asas ultimum remedium. Menarik kiranya bila hal tersebut dihubungkan dengan pendapat dari Sidharta, bahwa asas (principle) tidak dapat diterapkan langsung untuk menyelesaikan suatu peristiwa hukum konkret karena adanya kekurangan aspek formal sebagai proposisi hukum. Kekurangan ini muncul karena jurang (ketiadaan penghubung) antara fakta operatif (operative fact) dan akibat hukum (legal consequence). Hal ini membuat asas memang tidak bisa langsung diterapkan ke fakta, tetapi ia dapat membantu menunjuk peraturan mana yang paling tepat untuk digunakan dalam penyelesaian suatu kasus konkret.24 Seperti dikatakan Dedy Triyanto dan kawan-kawan bahwa suatu norma/ aturan hukum (rechtsregel) memiliki isi yang jauh lebih konkret, yang dapat diterapkan secara langsung. Berbeda dengan asas hukum yang daya kerjanya secara tidak langsung (indirect werking), yakni menjalankan pengaruh pada interpretasi terhadap aturan hukum. ${ }^{25}$ Asas hukum merupakan kaidah yang fundamental yang menjadi pikiran-

Hikmahanto Juwana, 'Penegakan Hukum dalam Kajian Law and Development: Problem dan Fundamen Bagi Solusi di Indonesia' (2006) 3 (2) Jurnal Indonesian Journal of International Law 212, 223-230.

24 Shidarta, 'Perbedaan Karakteristik Asas dengan Norma/Peraturan Hukum' (Universitas Binus, Juli 2016) <https://business-law.binus.ac.id/2016/07/15/perbedaan-karakteritik-asas-dannorma/> diakses 5 Maret 2019.

25 Dedy Triyanto Ari Rahmad, dkk, 'Hubungan Antara Norma Hukum dengan Asas Hukum' (2013) 1 (5) Jurnal Kertha Negara 1, 4. 
pikiran dasar yang terdapat di dalam suatu sistem hukum yang dirumuskan menjadi aturan-aturan perundang-undangan. Asas hukum mesti menjadi landasan dari norma hukum itu sendiri karena berada di sebalik aturan hukum itu.

Dalam menghadapi situasi krisis terhadap tipikor memang diperlukan langkah tepat dan tegas. Menarik kiranya yang dikatakan Suhardin bahwa konsep hukum mendatangkan interpretasi bebas dan banyak dipelintir dengan memanfaatkan dasar aturan-aturan karet yang ada. Hampir semua kasus besar KKN yang menyebabkan kerugian negara (baik materiil maupun moril) kebanyakan lolos lewat pintu hukum yang dinamakan prosedur atau kepastian hukum. ${ }^{26}$

Dalam penerapan sanksi kumulatif baik secara eksternal maupun internal mesti harus mengindahkan asas ne bis vexari, yang menghendaki bahwa dua sanksi atau lebih yang sifatnya sama tidak boleh diterapkan secara bersama-sama. Dalam kasus tersebut jelas sanksi pidana yang dikenakan adalah berupa penjara, denda dan uang pengganti, dan sanksi administrasi berupa pemberhentian dari jabatan sebagai anggota DPRD atau sebagai bupati. Dari sisi sifatnya memang semua sanksi tersebut berbeda-beda. Sanksi penjara bersifat membatasi ruang gerak seseorang. Sanksi denda bersifat memberikan beban keuangan. Sanksi pembayaran uang pengganti bersifat pengembalian kerugian uang negara atau pengganti kerugian negara. Sanksi pemberhentian dari jabatan bersifat memutuskan hubungan hukum atau kedudukan hukum yang mempunyai konsekuensi bagi kewajiban dan hak-hak yang melekat pada jabatan tersebut. Oleh karena tidak ada yang sifatnya sama, maka dibolehkan untuk diterapkan secara bersama-sama.

Dari sisi pengaturan terjadi perkembangan dengan lahirnya Peraturan Pemerintah No. 48 Tahun 2016 tentang Tata Cara Pengenaan Sanksi Administratif Kepada Pejabat Pemerintahan. Dalam Peraturan Pemerintah tersebut diatur bahwa seorang pejabat pemerintahan dapat dikenakan sanksi administrasi berat berupa pemberhentian tetap bila melakukan pelanggaran tertentu berupa menyalahgunakan wewenang, menetapkan dan/atau melakukan keputusan dan/atau tindakan yang berpotensi memiliki konflik kepentingan, atau melanggar ketentuan kewajiban-kewajiban yang menimbulkan kerugian pada keuangan negara, perekonomian nasional, dan/atau merusak lingkungan hidup. Sanksi administrasi berat tersebut dapat dijatuhkan setelah melalui proses pemeriksaan internal. Dalam peraturan tersebut penjatuhan sanksi administrasi berat tidak didasarkan pada putusan pengadilan yang berkekuatan hukum tetap.

\section{PENUTUP}

Berdasarkan uraian sebagaimana tersebut di atas, maka pejabat publik yang melakukan tipikor juga dijatuhi sanksi kumulatif eksternal antara sanksi pidana dan sanksi administrasi, dengan pertimbangan bahwa perbuatan terdakwa berten- 
tangan dengan semangat bangsa dan negara Indonesia dalam pemberantasan tipikor. Selain itu perbuatan terdakwa juga melukai hati masyarakat serta tidak menjalankan tugas dan fungsinya sebagai aparatur negara dengan baik, bahkan masih ditambah dengan sanksi administrasi berupa pemberhentian sebagai pejabat pemerintahan. Kendala yang dihadapi dalam penerapan kumulasi sanksi eksternal adalah berupa terjadinya pertentangan antara ketentuan normatif dengan asas hukum, khususnya asas ultimum remedium dalam hukum pidana. Penulis berpendapat bahwa penjatuhan sanksi seperti itu tepat dan adil sebagai sarana pencegahan dan penindakan terhadap pelaku tipikor yang lebih besar dengan segala akibat kerugian keuangan negara yang dapat ditimbulkan.

\section{DAFTAR BACAAN}

\section{Buku}

Abidin AZ, Asas-asas Hukum Pidana Bagian Pertama (Alumni 1987).

Atmasasmita R, Globalisasi dan Kejahatan Bisnis (Kencana Prenada Media Group 2010).

De Haan P, et.al., Bestuursrecht in de Sociale Rechtsstaat (Kluwer Deventer 1986).

Ibrahim J, Teori \& Metodologi Penelitian Hukum Normatif (cet. 3, Bayu Media Publishing 2006).

Istanto FS, Penelitian Hukum (CV.Ganda 2007).

Marzuki PM, Penelitian Hukum (cet. 11, Kencana Prenada Media 2005).
Mertokusumo S, Penemuan Hukum Sebuah Pengantar (cet. 3, Liberty 2006).

Mertokusumo S, Mengenal Hukum Suatu Pengantar (Liberty 2007).

Soekanto S, Pengantar Penelitian Hukum (UI Press 1981).

Van Wijk HV \& Konijnenbelt W, Hoofdstukken van Administratief Recht (cet. 6, Gravenhage 1984).

Yohanes SP, Penegakan dan Perlindungan Hukum di Bidang Pajak ( PT. Salemba Empat 2007). Upaya Pembenahan (PT Grasindo 2009).

\section{Artikel Jurnal}

Bartama PAA dan Wisnubroto A, Urgensi Perubahan Paradigma Penegakan Hukum dalam Menghadapi Tantangan Era Kontemporer (2017) 33 (1) Jurnal Justitia et Pax.

Hadjon PM, 'Pengkajian Ilmu Hukum Dogmatik (Normatif)' (1994) 8 (1) (1994) Jurnal Yuridika FH Unair.

Hariadi TM, 'Perbandingan Penanganan Tindak Pidana Korupsi di Negara Singapura dan Indonesia' (2013) 2 (3) Jurnal Recidive.

Juwana H, 'Penegakan Hukum dalam Kajian Law and Development: Problem dan Fundamen Bagi Solusi di Indonesia' (2006) 3 (2) Jurnal Indonesian Journal of International Law.

Nansi WS, 'Gagasan Reformasi Kebijakan Pemasyarakatan Narapidana Korupsi dalam Upaya Mencegah Praktek Korupsi pada Lembaga Pemasyarakatan' (2018) 34 (2) 
Jurnal Justitia et Pax.

Rahmad DTA, dkk, 'Hubungan Antara Norma Hukum dengan Asas Hukum' (2013) 1 (5) Jurnal Kertha Negara.

S Laurensius A, Mewujudkan Penegakan Hukum yang Baik di Negara Hukum Indonesia (2019) 11 (1) Jurnal Dialogia Iuridica.

Suhardin Y, 'Fenomena Mengabaikan Keadilan dalam Penegakan Hukum' (2009) 21 (2) Mimbar Hukum.

Suparman E, 'Menolak Mafia Peradilan: Menjaga Integritas Hakim Menyelaraskan Perbuatan (2017) 47 (1) Jurnal Hukum \& Pembangunan.

\section{Konferensi/Seminar}

Zulfadli M, Abdullah $\mathrm{K}$ dan Nur F, 'Penegakan Hukum yang Responsif dan Berkeadilan Sebagai Instrumen Perubahan Sosial Untuk Membentuk Karakter Bangsa' (Seminar Nasional "Pendidikan Ilmu-Ilmu Sosial Membentuk Karakter Bangsa Dalam Rangka Daya Saing Global" Kerjasama: Fakultas Ilmu Sosial Universitas Negeri Makassar dan Himpunan Sarjana Pendidikan Ilmu-ilmu Sosial Indonesia, Makassar, 29 Oktober 2016).

\section{Website}

Alkostar A, 'Korupsi Sebagai Extra Ordinary Crime dan Tugas Yuridis Para Hakim' (Mahkamah Agung, 28 Mei 2013) <https:/ / bawas.mahkamahagun g.go.id/component/content/arti cle/3-artikel-khusus-badan-pen gawas/323-korupsi-sebagai-ext ra-ordinary-crime-dan-tugas-yur idis-para-hakim> diakses 10 Desember 2019.

Anonim, 'Dashboard Pegawai' (Badan Kepegawaian Kabupaten Sleman) <https://bkpp.slemankab.go.id/ dashboard-pegawai/> diakses 5 Januari 2020.

Shidarta, 'Perbedaan Karakteristik Asas dengan Norma/Peraturan Hukum' (Universitas Binus, Juli 2016) <https://business-law. binus.ac.id/2016/07/15/perbed aan-karakteritik-asas-dan-norm a/> diakses 5 Maret 2019.

\section{Koran}

Atmasasmita R, 'Masalah Krusial Pemberantasan Korupsi di Indonesia' Koran SINDO 16 Oktober 2015).

\section{Putusan Pengadilan}

Putusan Pengadilan Negeri Sleman Nomor 271/Pid.B/20098/ PN.Slmn. 
